\title{
Home-Based Exercise and Patellar Bracig in the Treatment of Patellofemoral Pain Syndrome
}

\section{Patellofemoral Ağrı Sendromu Tedavisinde Ev Egzersiz Programı ve Patellar Breys Kullanımı}

\author{
Deniz EVCIK, Illhami KURU*, Saime AY, Gökhan MARALCAN** \\ Ufuk Üniversitesi Tıp Fakültesi, Fiziksel Tıp ve Rehabilitasyon Anabilim Dalı, Ankara, Türkiye \\ *Başkent Üniversitesi Tıp Fakültesi, Ortopedi Anabilim Dalı, Ankara, Türkiye \\ **Kocatepe Üniversitesi Tıp Fakültesi, Ortopedi Anabilim Dalı, Afyonkarahisar, Türkiye
}

Summary

Objective: The quadriceps muscle group plays an important role in patellar stabilization. This study was designed to investigate the effect of a quadriceps exercise program along with a patellar brace in reducing pain and increasing function in patello-femoral pain syndrome (PFPS) patients.

Materials and Methods: A total of 86 patients with PFPS were included in this study. Patients were randomized into two groups: Group $1(n=45)$ received a home based exercise program only; group $2(n=41)$ received the same home based exercise program along with a patellar brace. The duration of the intervention was six weeks. At the end of the therapy patients were evaluated for pain and functional capacity. Pain was assessed using the visual analogue scale (VAS) and the Western Ontario McMaster Osteoarthritis Index (WOMAC) Pain Scale. Functional capacity was evaluated by using the WOMAC Functional Capacity Index and the Fulkerson-Shea Patellofemoral Evaluation Score (FSPES).

Results: After the program, there were statistically significant decreases in the VAS and WOMAC pain scale for both group 1 and 2 ( $p<0.001)$. Also, statistically significant increases were observed in the WOMAC functional capacity index and the FSPES for both groups $(p<0.001)$. There were no statistical differences among parameters between two groups ( $p>0.05$ ). Conclusion: Addition of patellofemoral brace to the home exercise program didn't provide statistically significant differences in decreasing pain and increasing the functional capacity in patients with PFPS. Turk J Phys Med Rehab 2010;56:100-4.

Key Words: Patellofemoral pain, exercise, patellar brace, functional capacity
Özet

Amaç: Patellanın stabilizasyonunda kuadriseps kas grubu önemli rol oynar. Bu çalışmada patellofemoral ağrı sendromu (PFAS) olan hastalarda ev egzersiz programı ile ev egzersiz programına patellar breys eklemenin ağrı ve fonksiyonel kapasite üzerine etkisini araştırmak amaçlandı.

Gereç ve Yöntem: Çalışmaya PFAS olan 86 hasta dahil edildi. Hastalar iki gruba randomize edildi. Grup $1(n=45)$ hastalara yalnız ev egzersiz programı, grup $2(n=41)$ hastalara ev egzersiz programına ilave patellar breys verildi. Hastalar altı hafta boyunca tedaviye alındı. Tedavi sonunda ağrı ve fonksiyonel kapasite düzeyleri değerlendirildi. Ağrı; görsel anolog skala (GAS) ve Western Ontario McMaster Osteoartrit (WOMAC) Ağrı İndeksi ile değerlendirildi. Fonksiyonel kapasite ise WOMAC ve Fulkerson-Shea Patellofemoral Değerlendirme Skoru (FSPDS) ile değerlendirildi.

Bulgular: Tedavi sonrası, Grup 1 ve 2'de GAS ve WOMAC ağrı skorunda istatistiksel anlamlı azalma gözlendi $(p<0,001)$. Aynı zamanda her iki grupta WOMAC fonksiyonel indeks ve FSPDS'unda istatistiksel anlamlı artış gözlendi $(p<0,001)$. Gruplar arasında değerlendirme parametreleri açısından istatistiksel anlamlı fark yoktu.

Sonuç: PFAS olan hastalarda ev egzersiz programına patellar breys ekleme, yalnız ev egzersiz programına göre ağrı ve fonksiyonel kapasite üzerinde istatistiksel anlamlı bir düzelme göstermedi. Türk Fiz Tıp Rehab Derg 2010;56:100-4.

Anahtar Kelimeler: Patellofemoral ağrı, egzersiz, patellar breys, fonksiyonel kapasite 


\section{Introduction}

Patellofemoral pain syndrome (PFPS) is one of the most common disorders of the knee and is affecting an estimated $7-40 \%$ of adolescents and younger adults. The incidence of patellofemoral (PF) pain is higher in females than in males $(1,2)$. In PFPS, the clinical symptoms are diffuse peripatellar and retropatellar localized pain with prolonged knee flexion and crepitation during weight-bearing activities such as squatting, running or going up and down stairs. Despite the uncertain etiology, the predisposing factors in PF pain include articular cartilage damage from acute trauma, the presence of patella alta, increased $Q$ angle, femoral anteversion, iliotibial band length, overuse, excessive weight, and prolonged synovitis (1-4). Pain due to functional deficits may be a result of the medial quadriceps insufficiency, inflexibility of the lateral retinaculum, shortening of the hamstrings and gastrocnemius muscles and imbalances between the hip internal-external rotators and the quadriceps-hamstrings, respectively. In the chronic phase, the aim is to achieve maximum strength for the hip stabilizers, adductor magnus and vastus medialis obliquus (VMO) $(1,5,6)$.

The treatment goals are to reduce pain, prevent muscle atrophy and improve functional capacity, but no general consensus exists on the treatment approach (6). Conservative treatment methods include nonsteroidal anti-inflammatory drugs, bracing, taping, physical therapy, and strengthening and stretching exercises. Currently, exercise programs have been used mostly in the treatment of PFPS as a non-operative technique. Strengthening the extensor mechanism plays an important role in stabilizing the patella $(2,7)$. Most patients prefer home-based exercise program prescribed by a therapist, because it is easy, useful and there is no need for additional equipment. A Cochrane review summarized the evidence for treatment efficacy in reducing pain and improving functional capacity in patients with PFPS (8). The other commonly preferred non-operative treatment choice is patellar bracing, which is assumed to improve the knee alignment and tracking due to centralization of the patella, increased temperature, and neurosensory feedback. Nevertheless, the exact mechanism is still unclear $(3,9)$. The results of some clinical studies suggest that patellar bracing and exercise program may be successful in the treatment for reducing pain and increasing functional capacity. However, some investigators have described no clinical evidence to support the use of patellar bracing alone or patellar bracing along with exercise program for the treatment of PFPS (5,9-14).

This study was planned to reveal whether patellar bracing is of benefit in reducing pain and increasing functional capacity in patients with PFPS.

\section{Materials and Methods}

The clinical trial was carried out in the Department of Physical Medicine and Rehabilitation and in the Department of Orthopedics and Traumatology. Patients with PFPS were diagnosed by a physiatrist and orthopedic surgeon. A total of 86 patients (72 female, 14 males; aged 17-80 years), who had anterior or retropatellar knee pain when walking up and down stairs, squatting, kneeling or prolonged sitting for at least four weeks were enrolled in this study. In addition, they should have pain in at least two of the following physical tests: patellar compression test, in which pressure is applied over the patella while the knee is fully extended, Clarke's test (physician places his/her hand over the patient's patella, presses gently downwards, wants from the patient to contract the quadriceps muscle and the test is positive if pain occurs, which indicates PF problems), patellar apprehension test (the physician should be aware that patients with a history of subluxation or dislocation of the patella might feel very uncomfortable at this point and try to stop the physician from completing the test) and palpation of the posterior medial-lateral borders of the patella. Hypermobility (which is generally accepted risk factor for patellar dislocation and finally for instability), measurement of $Q$ angle and patellar tilt test were also applied. All patients underwent weight-bearing anteroposterior telemetric X-ray evaluation and tangential knee radiography in 30 and 45 degrees of flexion. Patellar subluxation (which was demonstrated by measuring the lateral PF angle), subchondral sclerosis and presence of degenerative changes were determined from these radiographs. All subjects were diagnosed as having PFPS based on history, physical examination, and radiological evaluation $(4,5,12)$. Patients with tibiofemoral compartment osteoarthritis, knee effusion, inflammatory joint pathology, infection, previous knee arthroplasty, lower extremity fracture history and severe cardiovascular diseases were excluded from the study.

After the physical examination, full blood count, erythrocyte sedimentation rate (ESR), C-reactive protein (CRP) and biochemical markers were evaluated in order to determine the presence of other systemic inflammatory diseases.

The study design was a prospective, single-blinded randomized controlled trial. After clinical and radiological evaluation, the patients were randomly allocated into either a home-based exercise program (group $1, n=45$ ) or home-based exercise program with patellar bracing (group 2, $n=41$ ). Randomization was made according to the consecutive admissions of the patients to the outpatient clinic. Before the therapy, the patients were evaluated by a physician, who also assessed the posttreatment outcomes. The physician was blinded to the treatment program. Only the physiotherapist who applied the therapy was aware of the procedure. The duration of the intervention was six weeks.

\section{Intervention}

Group 1 received a home-based exercise therapy including a standardized protocol developed by a physiotherapist and consisting of isometric and isotonic programs for quadriceps muscles. The exercises were noted on a workout paper and given to the patients. Each exercise was performed for one set of no fewer than ten repetitions, five times per week for six weeks. The program is given in appendix 1 .

Group 2 received the same home-based exercise program along with a patellar brace. The brace was a neoprene knee cuff with a patellar cutout (Altex Patellar knee support AL-2285C). It has special supportive material to pull the patella medially (Figure 1). The brace was applied throughout the day and removed during sleep.

During this program, patients were called every two weeks to monitor their compliance.

\section{Outcome Parameters}

Primary outcome parameters were pain and functional capacity. Pain was assessed using the visual analog scale (VAS) and the Western Ontario and McMaster Universities Osteoarthritis Index (WOMAC) pain scale (15). VAS scores range between $0-10 \mathrm{~cm}$ ( 0 indicating no pain, 10-severe pain). The WOMAC pain scale was scored using a 4-point Likert scale (0-4, higher scores indicating more pain). Functional capacity was assessed using the WOMAC functional capacity index and the 
Fulkerson-Shea Patellofemoral Evaluation (FSPE). The WOMAC functional capacity index was also assessed using 4-point Likert scale. The FSPE includes 7 separate items (each item has subgroups with different scores and the total score ranges from 0-100) (16).

Assessment parameters were measured before and after the exercise program (6 weeks).

Before treatment, all patients were informed about the trial and they gave written informed consent.

\section{Statistical Analysis}

The means and standard deviations were given as descriptive statistics. For determining the difference before and after treatment for all groups, the nonparametric Wilcoxon test was used. In order to compare the difference between the groups, the Mann-Whitney U test was applied. All analyses were completed using the software program SPSS 11.0 for Windows.

\section{Results}

The demographic and clinical features of all patients are shown in table 1 . The results of full blood count, ESR, CRP, and biochemical markers were within normal ranges for both groups.

All patients completed the regular exercise program. They did not report any adverse events caused by the exercise program or the brace at the end of the therapy (Figure 2).

\section{Pain}

After the therapy program, there were statistically significant decreases in both the VAS and the WOMAC pain scales in all patients $(p<0.001)$. However, there were no significant differences between the two groups ( $p>0.05)$.

\section{Functional Capacity}

We found statistically significant improvements in the WOMAC functional capacity index scores for all the patients $(p<0.001)$. Also there were increases in the FSPES scores for both groups $(p<0.001)$. However, the differences between the groups were not statistically significant $(p>0.05)$.

The results of the pain and functional capacity scores for both groups are shown in Tables 2, 3, and 4.

\section{Discussion}

PFPS is the most common cause of anterior knee pain and is used synonymously with chondromalacia patellae, PF chondritis and PF arthralgia (17). Female patients suffer more often from PFPS due to the increased anatomic femoral anteversion, which results in an increased $Q$ angle (18). Measurement of the standing $Q$ angle is an objective and specific physical finding for PFPS and it is accepted that its value should be less than 15 degrees. Studies have shown that increment of $Q$ angle increases the pressure on the lateral patellar facet, leading to lateral patellar tracking and possible subluxation $(19,20)$. Our study supports this conclusion as we

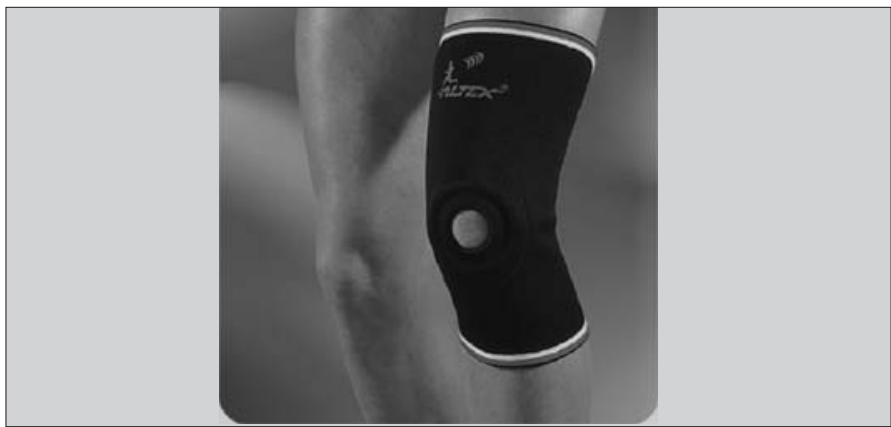

Figure 1. Patellar brace. observed an increased $Q$ angle in all patients, except eight in group 2.

There is no consensus on the management of chronic PFPS. In the acute phase, most patients respond to medical treatment, such as nonsteroidal anti-inflammatory drugs, which provide considerable pain relief. However, in the chronic phase, the vicious circle of pain, atrophy and instability should be prevented (21). Therefore, alternative treatment modalities are the key points. These include: patellar taping, bracing, physical therapy modalities and especially individualized quadriceps exercise programs $(22,23)$. Nevertheless, the most effective single therapy modalities have not been shown (1).

It is well known that an imbalance between the VMO and vastus lateralis (VL) may cause of PFPS. VMO is an important stabilizer of the PF joint and prevents lateral movement of the patella (24). Imbalance between these two muscles can lead to subluxation, and lateral patellar retinacular tightness can result in tilt of the patella. An isokinetic exercise training program was found to be effective in treating loss of extensor strength in PFPS, and it correlates with functional capacity (25). Isokinetic systems are expensive and may not be cost-effective. Various studies have reported the efficacy of conventional exercise programs in PFPS $(8,26)$. Syme's study showed the effectiveness of both general quadriceps strengthening and

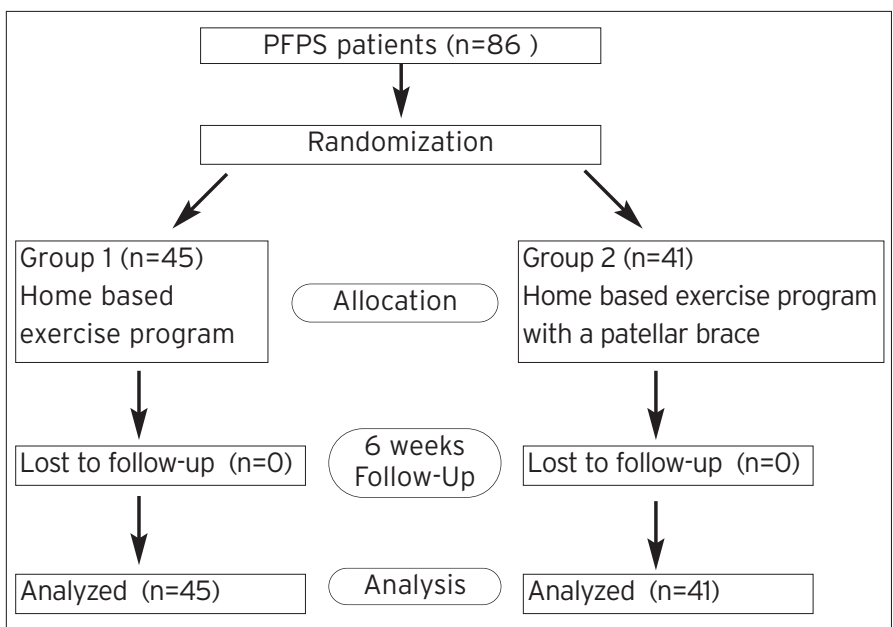

Figure 2. Flow diagram showing of patients through the clinical study.

Table 1. Demographic and clinical features of patello-femoral pain patients.

\begin{tabular}{|c|c|c|}
\hline & Group $1(n=45)$ & Group $2(n=41)$ \\
\hline Age (year) & $41 \pm 9.3(20-59)$ & $42.2 \pm 15.3(17-80)$ \\
\hline Gender (F/M) & $37 / 8$ & $35 / 6$ \\
\hline BMI $\left(\mathrm{kg} / \mathrm{m}^{2}\right)$ & $26.5 \pm 4.5(19-38)$ & $27.4 \pm 6.9(18-41)$ \\
\hline Disease duration (month) & $18.2 \pm 13.2(1-72)$ & $24.2 \pm 13.6(1-80)$ \\
\hline History of trauma(n) & 4 & 5 \\
\hline History of sports (n) & 7 & 4 \\
\hline Patellar compression test $(\mathrm{n})$ & 26 & 29 \\
\hline Clarke's test $(n)$ & 19 & 9 \\
\hline Patellar apprehension test (n) & 36 & 20 \\
\hline Patellar tilt test $(n)$ & 20 & 14 \\
\hline Patellar subluxation (n) & 6 & 4 \\
\hline Hypermobility (n) & 5 & 2 \\
\hline$Q$ angle (degree) & $18.6 \pm 2.4(15-24)$ & $14.9 \pm 3.5(10-26)$ \\
\hline
\end{tabular}


VMO specific training for pain relief and increasing functional capacity in PFPS patients. Both exercise programs can be beneficial for pain relief, providing a balance between $\mathrm{VMO}$ and VL. There was no difference between the approaches (5). Another trial compared the effectiveness of a six-week rehabilitation program consisting of strengthening the quadriceps and hip abductor musculature for reducing pain and increasing functional capacity. They reported that this exercise program was effective (10). In a randomized controlled trial carried out by Tyler et al. (27) it was concluded that exercise therapy resulted in significantly greater pain reduction and improvements in hip flexion strength combined with iliotibial band and iliopsoas flexibility. Dursun et al. (28) applied an electromyographic biofeedback treatment and compared it

Table 2. The results (mean \pm standard deviation) of group 1 and statistical comparison at baseline and after 6 weeks.

\begin{tabular}{|l|l|l|l|}
\hline \multicolumn{4}{|c|}{ Group 1 $(\mathrm{n}=45)$} \\
\hline & Pre-treatment & Post-treatment & $\mathrm{p}^{*}$ \\
\hline VAS & $7.1 \pm 1.4$ & $3.7 \pm 2.2$ & 0.000 \\
\hline WOMAC Pain & $8.3 \pm 3.3$ & $4.4 \pm 3.9$ & 0.000 \\
\hline WOMAC Func. & $25.0 \pm 11.2$ & $10.6 \pm 10.0$ & 0.000 \\
\hline FSPE & $64.3 \pm 12.5$ & $70.4 \pm 14.9$ & 0.000 \\
\hline
\end{tabular}

Group 1: Home-based exercise program, VAS: Visual Analog Scale, WOMAC: Western Ontario and McMaster Universities Osteoarthritis Index, Func: Functional Index, FSPE: Fulkerson-Shea Patellofemoral Evaluation, * Wilcoxon test.

Table 3. The results (mean \pm standard deviation) of group 2 and statistical comparison of the pre-treatment and post-treatment evaluations.

\begin{tabular}{|l|l|l|l|}
\hline \multicolumn{4}{|c|}{ Group 1 $(n=45)$} \\
\hline & Pre-treatment & Post-treatment & $p^{*}$ \\
\hline VAS & $6.4 \pm 2.6$ & $3.2 \pm 2.9$ & 0.000 \\
\hline WOMAC Pain & $7.3 \pm 3.4$ & $3.8 \pm 3.2$ & 0.000 \\
\hline WOMAC Func. & $23.8 \pm 15.2$ & $11.5 \pm 12.0$ & 0.000 \\
\hline FSPE & $63.2 \pm 18.5$ & $75.8 \pm 18.2$ & 0.000 \\
\hline $\begin{array}{l}\text { Group 2: Home-based exercise with patellar bracing, VAS: Visual Analog Scale, } \\
\text { WOMAC: Western Ontario and McMaster Universities Osteoarthritis Index, Func: } \\
\text { Functional Index, FSPE: Fulkerson-Shea Patellofemoral Evaluation, * Wilcoxon test. }\end{array}$ \\
\hline
\end{tabular}

Table 4. The results (mean \pm standard deviation) and statistical comparison of the pre-treatment and post-treatment evaluations between the groups.

\begin{tabular}{|c|c|c|c|}
\hline & Group $1(n=45)$ & Group $2(n=41)$ & $\mathrm{p}^{*}$ \\
\hline \multicolumn{4}{|l|}{ VAS } \\
\hline Pre-treatment & $7.1 \pm 1.4$ & $6.4 \pm 2.6$ & 0.240 \\
\hline Post-treatment & $3.7 \pm 2.2$ & $3.2 \pm 2.9$ & 0.222 \\
\hline \multicolumn{4}{|l|}{ WOMAC Pain } \\
\hline Pre-treatment & $8.3 \pm 3.3$ & $7.3 \pm 3.4$ & 0.152 \\
\hline Post-treatment & $4.4 \pm 3.9$ & $3.8 \pm 3.2$ & 0.670 \\
\hline \multicolumn{4}{|l|}{ WOMAC Func. } \\
\hline Pre-treatment & $25.0 \pm 11.2$ & $23.8 \pm 15.2$ & 0.449 \\
\hline Post-treatment & $10.6 \pm 10.0$ & $11.5 \pm 12.0$ & 0.941 \\
\hline \multicolumn{4}{|l|}{ FSPE } \\
\hline Pre-treatment & $64.3 \pm 12.5$ & $63.2 \pm 18.5$ & 0.640 \\
\hline Post-treatment & $70.4 \pm 14.9$ & $75.8 \pm 18.2$ & 0.078 \\
\hline \multicolumn{4}{|c|}{$\begin{array}{l}\text { Group 1: Home-based exercise program, Group 2: Home-based exercise with patellar } \\
\text { bracing, VAS: Visual Analog Scale, WOMAC: Western Ontario and McMaster } \\
\text { Universities Osteoarthritis Index, Func: Functional Index, FSPE: Fulkerson-Shea } \\
\text { Patellofemoral Evaluation, * Mann-Whitney U test. }\end{array}$} \\
\hline
\end{tabular}

with an exercise training program. They found an improvement in both pain and functional capacity, but no difference was observed between the two treatment modalities. The aim of the exercise program in this study was to reduce pain and increase functional capacity. For this purpose, pain was assessed using VAS and WOMAC pain scales. Functional capacity was evaluated by the WOMAC functional capacity index and the FSPES. In our study, we observed an improvement in both functional capacity and pain severity at the end of the sixth week in home exercise group. PF exercise program may be prescribed as a part of a rehabilitation program.

Although it is believed that PF joint stress is associated with PF pain, the effects of use of braces remain controversial. In his review, Grelsamer divided braces into two categories: passive and active (29). The passive brace kept the patella centered, while the active braces pulled the patella medially during knee flexion. Therefore, the passive braces were more effective in patients with patella alta and with no tilt. Simple bracing was found to provide pain relief by stabilizing the patella (30). In another study, the vacuumic brace in PFPS was found to be more effective in reducing pain and improving functional status and was able to create a joint distraction (4). Some other investigators noted that a brace should allow the free movement of the patella via a patellar cutout, and prolonged use should be avoided because of the risk of quadriceps atrophy $(31,32)$. According to the above-mentioned classification, our brace was a passive brace. Some other studies suggest an improvement in knee pain after patellar bracing and recommend using the patellar bracing in conjunction with a knee rehabilitation program $(11,12)$. Powers et al. (9) investigated the effect of bracing on PF joint stress during free and fast walking. They observed increases in PF contact area and joint reaction force, which resulted in decreased joint stress that was related to pain relief. Muhle et al. (33) using kinematic magnetic resonance imaging, analyzed patellar tracking patterns and found no statistically significant differences with the patellar realignment brace. The treatment of PFPS using the patellar brace was assessed by Timm et al. The treatment groups in this study were patellar bracing and control groups. Significant improvements were found in pain and functional capacity in all groups (13). Lun et al (12). investigated the effectiveness of patellar bracing in PFPS. They applied home exercise program alone, or with either patellar bracing or a knee sleeve over 12 weeks. They found an improvement in pain and functional capacity in all treatment groups. No difference was shown between bracing with home exercise and home exercise program. Another trial compared the effectiveness of home exercise program alone with this of home exercise program along with a patellar brace for pain relief during a three-week follow-up period. In addition, an improvement in pain was found, but no difference was observed between the two treatment modalities (14). In our study, we didn't find any additional benefit of using a brace in treating PFPS. As it is well known that there are various subgroups of PFPS, this result may be due to the fact that we did not distinguish between those subgroups.

In our study, we found no statistically significant differences in all outcome measures between the home-based exercise program and home-based exercise program along with a patellar brace groups of PFPS patients. However, there were improvements in pain and functional capacity in both groups. As various non-surgical treatment programs showed efficacy on pain relief and functional capacity in PFPS, still there is no therapy program accepted as a standard. Therefore, high-quality trials are necessary to confirm our results.

One limitation of this study was the absence of a control group of PFPS patients who received only patellar bracing, 
which would allow us to compare the effectiveness of patellar bracing alone. The other limitations were sample sizes small and short follow-up duration.

As a conclusion, the treatment of PFPS is controversial. Our study supports the contention that in the absence of the need for surgery, exercise therapy, especially for the VMO and quadriceps muscles, either alone or with a patellar brace, seems to be effective for pain relief and for improving functional capacity.

\section{Apendix 1.}

1. Isometric quadriceps exercise:

a. The patient lies on the floor with a towel under the knee and the leg extended. The patient contracts the quadriceps by pushing against the towel.

b. The patient sits on the edge of a chair with a pillow between the legs. The patient pushes up against the pillow, creating tension in the muscles but allowing no movement.

c. Isometric straight leg exercise: The patient lies supine, slowly contracts the thigh muscles and dorsiflexes the foot, then lifts the foot up $10 \mathrm{~cm}$ from the surface holding this position for 5 seconds.

2. Short-arc leg exercise: The patient lies in supine position with a pillow supporting the knee in 20 degrees of flexion. From this position, the leg is extended and held in this position for 5 seconds. Once this becomes easy, weight may be added to the ankle. This exercise is also done in standing position, moving from 0 to 30 degrees of knee flexion.

3. VMO strengthening and stretching exercises:

a. The patient lies supine and bends the hip and knee of one leg. The other leg is extended and spread aside with the toe pointing out. Then the extended leg is raised over the flexed leg. The patient holds this position for 5 seconds. Weight may be added as strength increases.

b. The exercise above is also performed in both supine and standing positions using rubber or theraband tubing.

c. The patient stands with legs spread, one leg straight, toes pointing straight ahead, and the other leg bent at the knee with the toes at a 45 degree angle. The patient then leans forward on the knee in 30-45 degrees and holds this position for 5 seconds. Once completed, this exercise is performed with the other leg.

\section{References}

1. Bizzini M, Childs JD, Piva SR, Delitto A. Systematic review of the quality of randomised controlled trials for patellofemoral pain syndrome. J Orthop Sports Phys Ther 2003:33:4-20. [Abstract] / [PDF]

2. Cowan SM, Bennell KL, Crossley KM, Hodges PW, McConnell J. Physical Therapy alters recruitment of the vasti in patellofemoral pain syndrome. Med Sci Sports Exerc 2002;34:1879-85. [Abstract]

3. Chew KT, Lew HL, Date E, Fredericson M. Current evidence and clinical applications of therapeutic knee braces. Am J Phys Med Rehabil 2007:86:678-86. [Abstract]

4. Roostayi MM, Bagheri H, Moghaddam ST, Firooznia K, Razi M, Hosseini M, et al. The effect of vacuumic bracing system on the patellofemoral articulation in patients with patellofemoral pain syndrome. Complement Ther Clin Pract 2009;15:29-34. [Abstract] / [PDF]

5. Syme $G$, Rowe $P$, Martin D, Daly G. Disability in patients with chronic patellofemoral pain syndrome: A randomised controlled trial of $\mathrm{VMO}$ selective training versus general quadriceps strenghthening. Man Ther 2009;14:252-63. [Abstract] / [Full Text] / [PDF]

6. Lowry CD, Cleland JA, Dyke K. Management of patients with patellofemoral pain syndrome using a multimodal approach: A case series. J Orthop Sports Phys Ther 2008;38:691-702. [Abstract] / [PDF]

7. Grana VA, Kriegshauser LA. Scientific basis of extensor mechanism disorders. Clin Sports Med 1985;4:247-57. [Abstract]

8. Heintjes E, Berger MY, Bierma-Zeinstra SM, Bernsen RM, Verhaar $J A$, Koes BW. Exercise therapy for patellofemoral pain syndrome. Cochrane Database Syst Rev 2003:4:3472. [Abstract] / [PDF]
9. Powers $C M$, Ward SR, Chen $Y$, Chan $L$, Terk MR. The effects of bracing on patellofemoral joint stress during free and fast walking. Am J Sports Med 2004;32:224-31. [Abstract] / [Full Text] / [PDF]

10. Boling MC, Bolgla LA, Mattacola CG, UhI TL, Hosey RG. Outcomes of a weight-bearing rehabilitation program for patients diagnosed with patellofemoral pain syndrome. Arch Phys Med Rehabil 2006; 87:1428-35. [Abstract] / [Full Text] / [PDF]

11. Powers CM, Ward SR, Chen YJ, Chan LD, Terk MR. Effect of bracing on patellofemoral joint stres while ascending and descending stairs. Clin J Sport Med 2004;14:206-14. [Abstract]

12. Lun VM, Wiley JP, Meeuwisse WH, Yanagawa TL. Effectiveness of patellar bracing for treatment of patellofemoral pain syndrome. Clin J Sport Med 2005;15:235-40. [Abstract]

13. Timm KE. Randomized controlled trial of Protonics on patellar pain, position, and function. Med Sci Sports Exerc 1998:30:665-70. [Abstract]

14. Miller MD, Hinkin DT, Wisnowski JW. The efficacy of orthotics for anterior knee pain in military trainees: a preliminary report. Am J Knee Surg 1997;10:10-3. [Abstract]

15. Bellamy N, Buchanan WW, Goldsmith $\mathrm{CH}$, Campbell J. Validation study of WOMAC: a health status instrument for measuring clinicallyimportant patient-relevant outcomes following total hip or knee arthroplasty in osteoathritis. J Orthop Rheumatol 1988;1:95-108.

16. Owens BD, Stickles BJ, Balikian P, Busconi BD. Prospective analysis of radiofrequency versus mechanical debridement of isolated patellar chondral lesions. Arthroscopy 2002;18:151-5. [Abstract] [Full Text] / [PDF]

17. Thomee $\mathrm{R}$, Augustsson J, Karlsson J. Patellofemoral pain syndrome: a review of current issues [review]. Sports Med 1999; 28:245-62. [Abstract]

18. Fulkerson JP, Arendt EA. Anterior knee pain in females. Clin Orthop 2000;372:69-73. [Abstract]

19. Blazer K. Diagnosis and treatment of patellofemoral pain syndrome in the female adolescent. Physician Assistant 2003:27:23-30.

20. Herrington L, Nester C. Q-angle undervalued? The relationship between $\mathrm{Q}$-angle and medio-lateral position of th patella. Clinical Biomechanics 2004:19:1070-3.

21. Malone T,Davies G, Walsh WM. Muscular control of the patella. Clin Sports Med 2002;21:349-62. [Abstract]

22. Crossley K, Bennell K, Green S, Cowan S, McConnell J. Physical therapy for patellofemoral pain: a randomized, double-blinded, placebo-controlled trial. Am J Sports Med 2002:30:857-65. [Abstract] / [Full Text] / [PDF]

23. Crossley $\mathrm{K}$, Cowan SM, Bennell $\mathrm{KL}$, McConnell J. Patellar taping: is clinical success supported by scientific evidence? Man Ther 2000;5:142-50. [Abstract] / [PDF]

24. Witrouw $E$, Sneyers $C$, Lysens $R$, Victor J, Bellemans J. Reflex response times of vastus medialis oblique and vastus lateralis in normal subjects and in subjects with patellofemoral pain syndrome. J Orthop Sports Phys Ther 1996;24:160-5. [Abstract] / [PDF]

25. Alaca R, Yılmaz B, Göktepe AS, Mohür H, Kalyon TA. Efficacy of isokinetic exercise on functional capacity and pain in patellofemoral pain syndrome. Am J Phys Med Rehabil 2002;81:807-13. [Abstract]

26. Callaghan $M$, Oldham J. The role of quadriceps exercise in the treatment of patellofemoral pain syndrome. Sports Med 1996;21:384-91. [Abstract]

27. Tyler TF, Nicholas SJ, Mullaney MJ, McHugh MP. The role of hip muscle function in the treatment of patellofemoral pain syndrome. Am J Sports Med 2006;34:630-6. [Abstract] / [Full Text] / [PDF]

28. Dursun N, Dursun E, Kiliç Z. Electromyographic biofeedbackcontrolled exercise versus conservative care for patellofemoral pain syndrome. Arch Phys Med Rehabil 2001;82:1692-5. [Abstract] / [Full Text] / [PDF]

29. Grelsamer RP. The nonsurgical treatment of patellofemora disorders. Operative Techniques in Sports Medicine 1999:7:65-8. [Abstract] / [PDF]

30. Fulkerson JP. Patellofemoral pain disorders: Evaluation and management. J Acad Orthop Surg 1994;2:124-32. [Abstract] / [PDF]

31. Zappala F, Taffel CB, Scuderi GR. Rehabilitation of patellofemora joint disorders. Orthop Clin North Am 1992;23:555-66. [Abstract]

32. Tria AJ Jr, Palumbo RC, Alicea JA. Conservative care for patellofemoral pain. Orthop Clin North Am 1992:23:545-54. [Abstract]

33. Muhle C, Brinkmann G, Skaf A, Heller M, Resnick D. Effect of a patellar realignment brace on patients with patellar subluxation and dislocation. Evaluation with kinematic magnetic resonance imaging. Am J Sports Med 1999:27:350-3. [Abstract] / [Full Text] / [PDF] 